\title{
Study of Neptunium, Americium and Protactinium Addition for 300MWth GFR with Uranium Carbide Fuel
}

\author{
Ratna Dewi Syarifah ${ }^{1, a}$ and Alvi Nur Sabrina ${ }^{2}$ \\ ${ }^{1}$ Department of Physics, Faculty of Mathematics and Natural Sciences, Universitas Jember, \\ Jalan Kalimantan No. 37 Jember 68121 \\ ardsyarifah.fmipa@unej.ac.id
}

\begin{abstract}
A study of Neptunium, Americium, and Protactinium addition for GFR 300MWth with Uranium Carbide fuel has been performed. The purpose of this study was to determine the characteristics of addition Neptunium, Americium, and Protactinium in a 300MWth Gas-Cooled Fast Reactor. Neutronics calculation was design by using Standard Reactor Analysis Code (SRAC) version 2006 with data nuclides from JENDL-4.0. Neutronics calculations were initiated by calculating the fuel cell calculation (PIJ calculation) and continued with the reactor core calculation (CITATION calculation). The reactor core calculation used two-reactor core configurations, namely the homogeneous core configuration and heterogeneous core configuration. The Neptunium, Americium, and Protactinium additions were performed after obtaining the optimal condition from heterogeneous core configuration. The addition of Neptunium and Americium which are Spent Nuclear Fuel (SNF) from LWR fuels, aims to reduce the amount of Neptunium and Americium in the world and also to reduce the effective multiplication factor $(k-$ eff) value from the reactor. The results obtained that the addition of Neptunium and Americium causes the $k$-eff value was decreased at the beginning of burn-up time, but increase at the end of burn-up time. It was because Neptunium and Americium absorb neutrons at the beginning of burn-up time and turns into fissile material at the end of burn-up time. The addition of protactinium in the reactor causes the $k$-eff value to be decreased both at the beginning of the burn-up time and at the end of the burn-up time. It happens because Protactinium absorbs neutrons both at the beginning of the burn-up time and at the end of the burn-up time. Therefore protactinium is often called a burnable poison.
\end{abstract}

Keywords: GFR, Uranium Carbide, Neptunium, Americium, Protactinium

\section{Introduction}

Nuclear reactor generation IV are reactors formed from the development of generation III $^{+}$ reactors. Generation IV reactor consists of six reactor types, i.e. Gas-Cooled Fast Reactor (GFR), Lead Cooled Fast Reactor (LFR), Molten Salt Reactor (MSR), Sodium Cooled Fast Reactor (SFR), Supercritical Water-Cooled Reactor (SCWR), and Very High-Temperature Reactor (VHTR). There are several advantages of generation IV reactors, i.e. inherent safety, sustainability, non-proliferation resistances, and economic competitiveness [1-2]. A Gas-Cooled Fast Reactor (GFR) is one of the gas reactors that emerged as the Generation IV reactors. GFR is one candidate for generation IV nuclear power reactor which is estimated to be used in 2030. Neutronic calculation about GFR with Uranium Plutonium Nitride and Thorium Nitride as a fuel has been calculated before with varies of power, geometry, and actinide minor addition [3-12]. In this study, the neutronics calculation of GFR used Uranium Carbide as fuel and added Neptunium, Americium, and Protactinium as spent nuclear fuel. The purpose of this study was to determine the characteristics of the addition of Neptunium, Americium, and Protactinium on Uranium Carbide fuel. The addition of minor actinides on the fuel used in the modular Gas- 
Cooled Fast Reactor is one of the right actions to reduce the waste of residual LWR fuel in the world.

\section{Theoretical Background}

A nuclear reactor is a controlled fission chain reaction. Based on the neutron energy used to maintain the fission reaction, there are two types of reactor, i.e. thermal reactors and fast reactors. GFR is a reactor that uses a fast neutron spectrum and uses a coolant in the form of Helium (He). The high temperature generated in the GFR, allows this reactor to be used as a power plant in the future. The addition of minor actinides, which are recycled fuels from LWR waste, has the advantage of reducing radioactive waste in the world. The Neptunium and Americium have a large percentage of LWR used fuel and have a half-life of hundreds to millions of years [13]. Neutronics calculation in the nuclear reactors can be performed using the following programs, i.e. RELAP, ORIGIN-8, AutoCAD 20108, LabView, ArcGIS-10, Understand 2.6, MATLAB, SRAC, etc. [14]. Neutronics calculation in this study was performed by using the Standard Reactor Analysis Code (SRAC) which is a program of code analysis and design for nuclear reactors. SRAC has a library or data set on neutron cross-section, additional codes used in the analysis of nuclear reactor design, routines or movements of the neutron spectrum, neutron transport, one group - multi-group diffusion, etc. [15]. The database was used in the SRAC code, i.e. JENDL, ENDF/B, and JEF which have more than 300 nuclide data. This study using SRAC ver 2006 with the JENDL-4.0 database which is the latest version of nuclide data from JENDL.

\section{Materials and Methods}

Table 1 shows the reactor design specifications. The specifications include the specification of the core and the fuel that had been used. The fuel cell pin used in this study is the hexagonal cell. The hexagonal cell geometry in this study is divided into six regions, the first three are fuel regions, the next two regions are cladding, and the next two regions are coolant. The division of the region can be seen in Figure 1 and the sub-region from hexagonal cell geometry can be seen in Figure 2.

Table 1. Reactor design specifications

\begin{tabular}{cll}
\hline No. & Parameter & Specification \\
\hline 1. & Fuel /Cladding /Coolant & UC/ SiC/ He \\
2. & Fuel volume fraction & $60 \%$ \\
3. & Cladding volume fraction & $10 \%$ \\
4. & Coolant volume fraction & $40 \%$ \\
5. & Minor actinide & Neptunium-237 and Americium \\
6. & Pin pitch & $1.45 \mathrm{~cm}$ \\
7. & Burnable poison & Protactinium-231 \\
8. & Percentage U-235 & $5 \%-15 \%$ \\
9. & Percentage Protactinium-231 & $0.5 \%-4 \%$ \\
10. & Percentage Neptunium-237 & $0.5 \%-5 \%$ \\
11. & Percentage Americium & $0.5 \%-5 \%$ \\
12. & Power & $300 \mathrm{MWth}$ \\
13. & Burn-up time & $>20$ years \\
14. & Core geometry & Cylinder pancake \\
15. & Fuel pin cell & Hexagonal cell \\
16. & Height active core & $100 \mathrm{~cm}$ \\
17. & Diameter active core & $240 \mathrm{~cm}$ \\
18. & Reflector & $50 \mathrm{~cm}$ \\
\hline
\end{tabular}




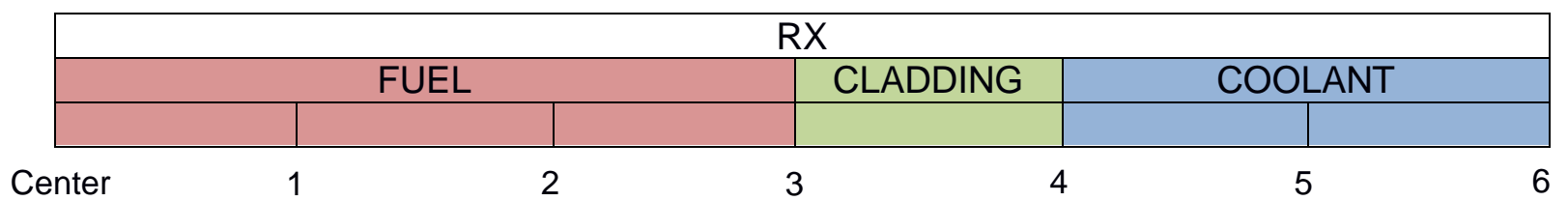

Figure 1. Regional division in fuel pin calculation

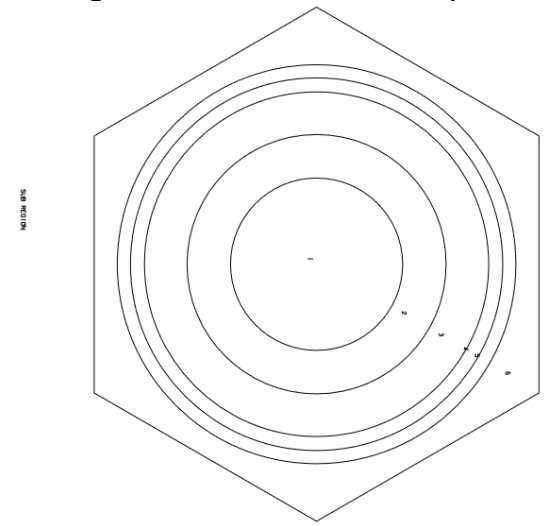

Figure 2. Sub-region hexagonal cell geometries

The calculation method uses SRAC 2006 with the JENDL-4.0 database. The first step of calculation was the calculation of fuel pin cell (PIJ calculation) and the second step was reactor core calculation (CITATION calculation). The calculation for PIJ and CITATION used two core configurations, i.e. homogeneous and heterogeneous core configurations. The homogeneous core configuration used one type of percentage of Uranium-235. And the heterogeneous core configuration used three types of the percentage of Uranium-235 in the reactor core. The Uranium-235 is used as fissile material in the reactor core.

\section{Results and Discussion}

The neutronics calculation began with the calculation of the homogeneous core configurations. The homogeneous core configurations used percentage 5\% - 15\% of Uranium-235. The results obtained indicate that the fuel variations with the average U-235 value of $12 \%$ showed the most critical condition. Based on the results of the homogeneous core configuration i.e. percentage $12 \%$ of U-235, it became referred to as calculate heterogeneous core configuration. Table 2 shows fuel variations used in the calculations of heterogeneous core configurations.

Table 2. Variation of U-235 in heterogeneous core calculation

\begin{tabular}{c|c}
\hline Number of case & Composition (\%) \\
\hline Case 1 & $\mathrm{F} 1=10 \%, \mathrm{~F} 2=12 \%, \mathrm{~F} 3=14 \%$ \\
Case 2 & $\mathrm{F} 1=9 \%, \mathrm{~F} 2=12 \%, \mathrm{~F} 3=15 \%$ \\
Case 3 & $\mathrm{F} 1=11 \%, \mathrm{~F} 2=12 \%, \mathrm{~F} 3=13 \%$ \\
Case 4 & $\mathrm{F} 1=10.5 \%, \mathrm{~F} 2=12 \%, \mathrm{~F} 3=13.5 \%$ \\
Case 5 & $\mathrm{F} 1=9.5 \%, \mathrm{~F} 2=12 \%, \mathrm{~F} 3=14.5 \%$ \\
\hline
\end{tabular}

Figure 3 shows the result of heterogeneous core configuration. The result shows that variations in case $2(\mathrm{~F} 1=9 \%, \mathrm{~F} 2=12 \%, \mathrm{~F} 3=15 \%)$ are the variation with the most stable $k$-eff value from the 
beginning till the end of burn-up time. Maximum excess reactivity obtained on average $6 \%$ $\Delta k / k \%$.

Figure 4 shows the comparison of average power density in homogeneous and heterogeneous core configurations. The average power density in homogeneous core configuration has a peaking power in the center of the reactor core, while in heterogeneous core configuration has a flat value of average power density in the center of the reactor core. Based on the results obtained, the average power density in the heterogeneous core configuration indicates a safer condition to using in the operation of the reactor. Therefore, the calculation in the next step uses a core with a heterogeneous configuration. The comparison of average power density value and maximum power density value in homogeneous and heterogeneous core configurations are shown in Table 3.

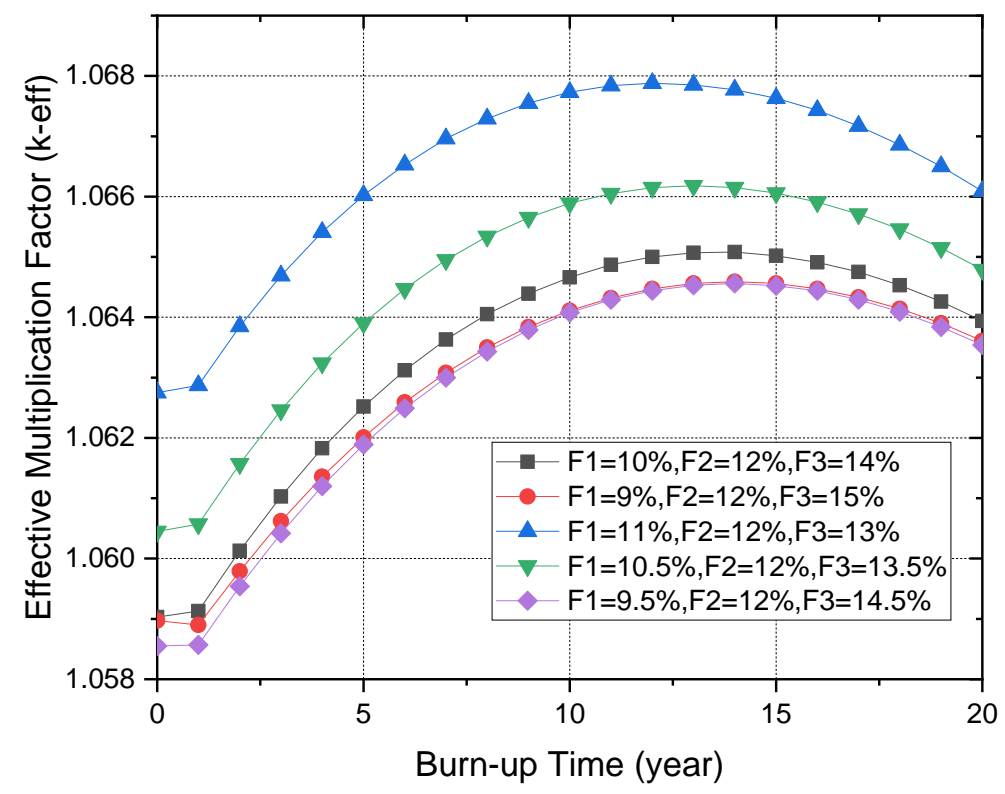

Figure 3. Effective multiplication factor ( $k$-eff) value of heterogeneous core configuration 


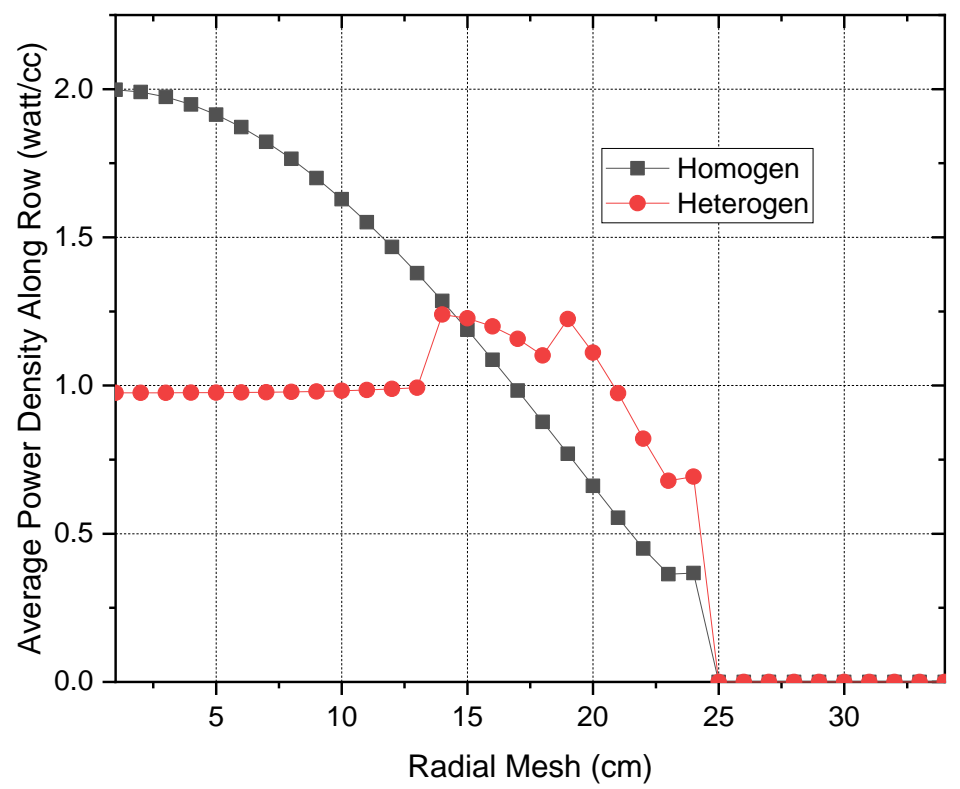

Figure 4. Comparison of average power density value in homogeneous core configuration and heterogeneous core configuration

Table 3. Comparison of average power density and maximum power density in homogeneous and heterogeneous core configuration

\begin{tabular}{cccc}
\hline Core configuration & Case & $\begin{array}{c}\text { Average power } \\
\text { density (watt/cc) }\end{array}$ & $\begin{array}{c}\text { Maximum power } \\
\text { density (watt/cc) }\end{array}$ \\
\hline Homogeneous & $\mathrm{U}-23512 \%$ & 87.9 & 175 \\
Heterogeneous & $\mathrm{F} 1=9 \%, \mathrm{~F} 2=12 \%$, & 78.6 & 97 \\
\end{tabular}

After calculated heterogeneous core configuration, it was necessary to add Neptunium-237 and Americium in the reactor. Neptunium-237 and Americium are one of minor actinide nuclide. Minor actinides are residual fuel obtained from light water reactor (LWR) waste. Minor actinides are commonly referred to as spent nuclear fuel (SNF) which has a relatively long half-life and a high level of toxicity. This study used the minor actinides of the nuclides Neptunium-237 and Americium because it was the most abundant LWR fuel waste. Figure 5 and 6 shows the effective multiplication factor ( $k$-eff) value of Neptunium and Americium addition in the UC fuel. 
Computational and Experimental Research in Materials and Renewable Energy (CERiMRE)

Volume 2, Issue 2, page 64-71

eISSN : 2747-173X
Submitted : July 8, 2019

Accepted : September 8, 2019

Online : November 24, 2019

doi : $10.19184 /$ cerimre.v2i2.27368

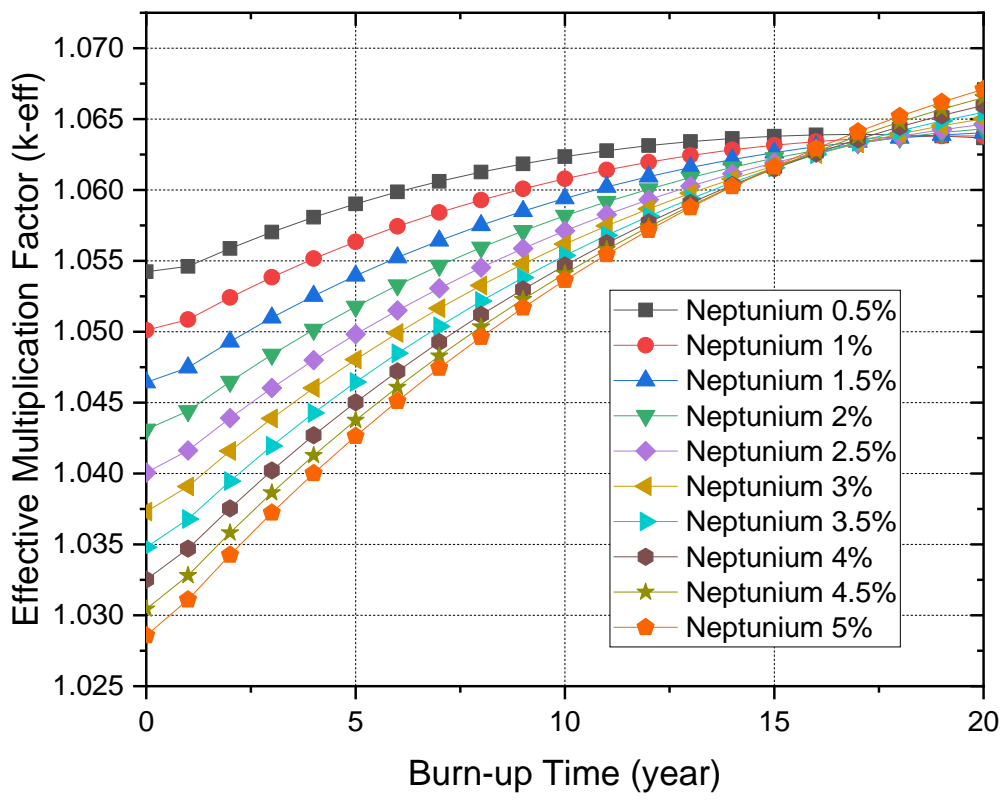

Figure 5. Effective multiplication factor ( $k$-eff) value of Neptunium addition in the UC fuel

Figure 5 and 6 shows that Neptunium-237 and Americium decreased the $k$-eff values at the beginning of the burn-up time and increased the $k$-eff value at the end of burn-up time. The greater variation of the Neptunium-237 and Americium given, the greater decreased of $k$-eff value at the beginning of burn-up time. It happened because Neptunium-237 and Americium has cross-section absorption greater than fissile material. Therefore, the $k$-eff value decreased at the beginning of burn-up time. After absorbing the neutrons, the Neptunium-237 and Americium would become fissile material (Pu-239), so at the end of burn-up time the k-eff value increase.

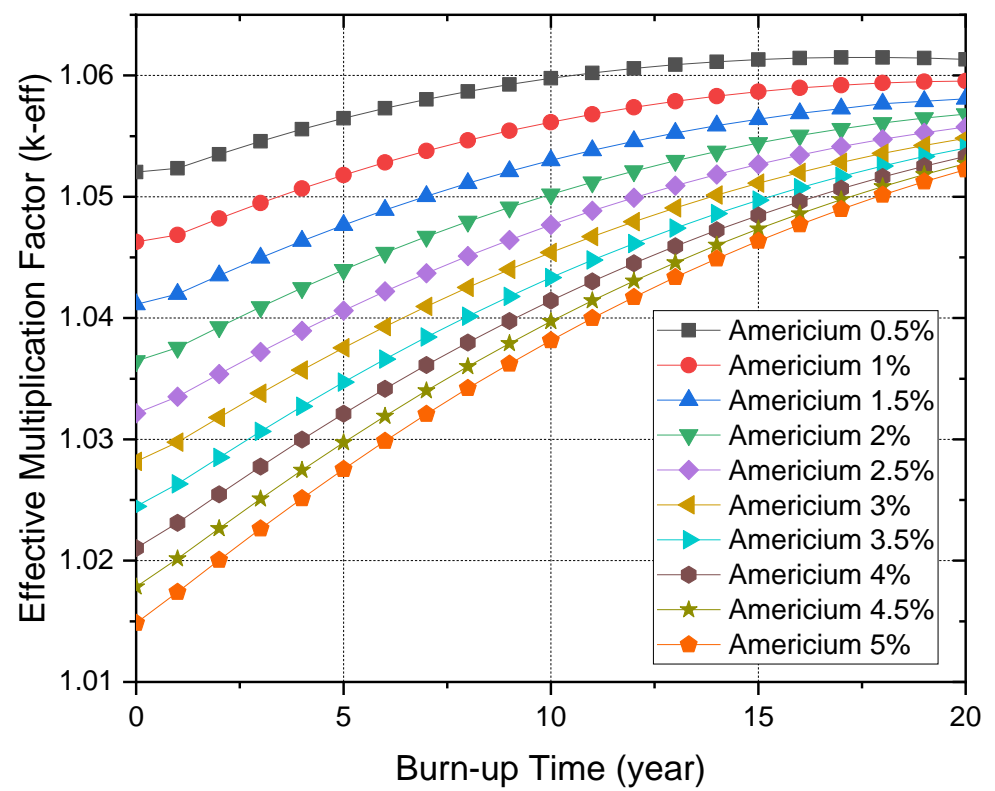

Figure 6. Effective multiplication factor ( $k$-eff) value of Americium addition in the UC fuel 
After that, it was necessary to add burnable poison in the core reactor to decrease $k$-eff value to become critical. The burnable poison used in this study is Protactinium (Pa-231). Protactinium has high cross-section neutron absorption. $\mathrm{Pa}-231$ absorbed neutrons at the beginning of the burn-up time, causing the k-eff value was decreased. Figure 7 shows the result of heterogeneous core configuration with the addition of $\mathrm{Pa}-231$. The variation of $\mathrm{Pa}-231$ used between $0.5 \%$ up to $4 \%$ with an interval 0.5 . The addition of Pa-231 $3.5 \%$ had the optimum $k$-eff value $(k$-eff $\sim 1)$ with a maximum excess reactivity obtained $1.04 \% \Delta \mathrm{k} / \mathrm{k} \%$.

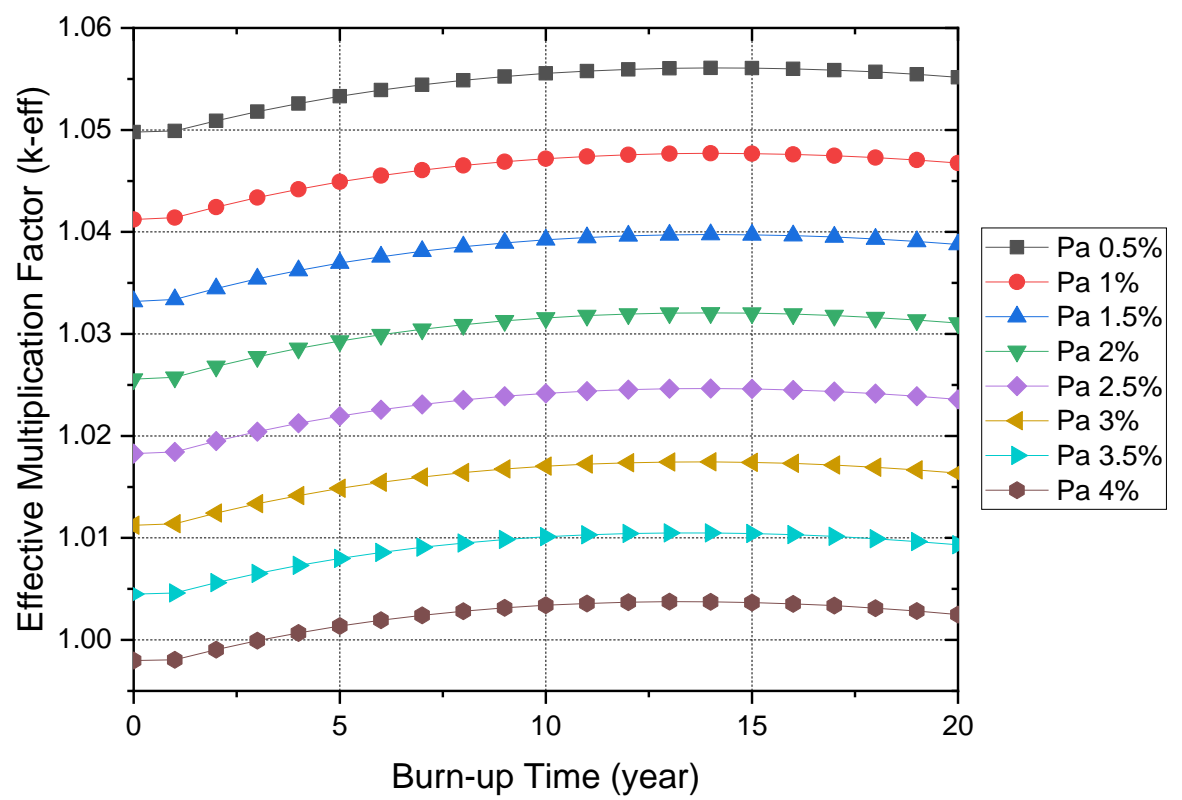

Figure 7. Effective multiplication factor ( $k$-eff) value of addition Protactinium-231

\section{Conclusions}

Neptunium-237 and Americium decreased the k-eff value at the beginning of burn-up time and increased the $k$-eff value at the end of burn-up time. At the beginning of burn-up time, the Neptunium-237 and Americium absorbed the neutron and become fissile material (Pu-239 and Pu-241). Therefore it increased the burn-up time at the end of burn-up. Protactinium is called burnable poison. It decreased the $k$-eff value both at the beginning and the end of burn-up time.

\section{References}

[1] GIF (The Generation IV International Forum) and the OECD Nuclear Energy Agency, 2014, Technology Roadmap Update for Generation IV Nuclear Energy System.

[2] GIF (The Generation IV International Forum) and the U.S DOE Nuclear Energy Advisory Commite, 2002, A Technology Roadmap for Generation IV Nuclear Energy System.

[3] R. D. Syarifah, Y. Yulianto, Z. Su'ud, K. Basar, and D. Irwanto, 2016, Neutronic Analysis of Thorium Nitride (Th, U233)N Fuel for 500 MWth Gas Cooled Fast Reactor (GFR) Longlife without Refueling, Key Engineering Materials, Vol. 733, page 47-50. 
[4] R. D. Syarifah, Z. Su'ud, K. Basar, and D. Irwanto, 2016, Design Study of 200 MWth Gas Cooled Fast Reactor with Nitride (UN-PuN) Fuel Long Life without Refueling, MATEC Web of Conferences.

[5] R. D Syarifah, Z. Su'ud, K. Basar, and D. Irwanto, 2016, The prospect of Uranium Nitride (UN-PuN) Fuel for 25-100 Mwe Gas Cooled Fast Reactor Long Life without Refueling, Journal of Physics, Conference Series 776.

[6] R. D Syarifah, Z. Su'ud, K. Basar, and D. Irwanto, 2017, Fuel Fraction Analysis of 500 MWth Gas Cooled Fast Reactor with Nitride (UN-PuN) Fuel without Refueling, IOP Conf. Series : Journal of Physics, Conference Series 799.

[7] R. D. Syarifah, Z. Su'ud, D. Irwanto, K. Basar, S. C. Pattipawaej, and M. Ilham, 2017, Comparison of Uranium and Thorium Nitride Fuel for 500 MWth Gas Cooled Fast Reactor (GFR) Longlife without Refueling, International Journal of Research, Special Issue Paper, page 1-7.

[8] R. D. Syarifah, Z. Su'ud, K. Basar, and D. Irwanto, 2017, Comparative Study on Various Geometrical Core Design of 300 MWth Gas Cooled Fast Reactor with UN-PuN Fuel Longlife without Refueling, IOP Conf. Series : Journal of Physics, Conference Series 877.

[9] R. D. Syarifah, Z. Su'ud, K. Basar, and D. Irwanto, 2018, Neutronic Analysis of UN-PuN Fuel use FI-ITB-CHI Code for 500 MWth GFR Long-life without Refueling, IOP Conf. Series:Journal of Physics, Conf. Series 1090.

[10] M. A. Fareha, R. D. Syarifah, Z. Su'ud, K. Basar, and N. Kuniarsih, 2018, Design Study of 600 MWt Long-life Modular Gas Cooled Fast Reactors, IOP Conf. Series : Journal of Physics : Conf. Series 1090.

[11] R. D. Syarifah, 2018, Design and Neutronic Analysis Nuclear Power Modular Reactor Type GFR (Gas Cooled Fast Reactor) without Refueling, Disertasi, FMIPA-Fisika : Institute Technology Bandung.

[12] Z. Su'ud, 2014, Design Study of Small Gas Cooled Fast Nuclear Power Plant for Synergic Energy System with Renewable Energy by Employing Pump Storage, Advanced Material Research, Vol. 983, page 233-237.

[13] IAEA, 2009, Status of Minor Actinide Fuel Development, Vienna : International Atomic Energy Agency, ISSN : 1995-7807.

[14] K. Tsuchihashi, H. Takano, K. Horikami, Y. Ishiguro, K. Kaneko, and T. Hara, 1983, SRAC : JAERI Thermal Reactor Standard Code System for Reactor Design and Analysis, Japan : Japan Atomic Energy Research Institue (JAERI).

[15] K. Okumura, T. Hugo, K. Kaneko, and K. Tsuchihashi, 2002, SRAC (Ver. 2002): The Comprehensive Neutronics Calculation Code System, Japan : Japan Atomic Energy Research Institue (JAERI). 